\title{
ВПЛИВ ЕПОКСИКОНАЗОЛУ НА ГЕМАТОЛОГІЧНІ ТА ЦИТОХІМІЧНІ ПОКАЗНИКИ ПЕРИФЕРИЧНОÏ КРОВІ ЩУРІВ WISTAR HANNOVER
}

Вступ. Епоксиконазол - високоефективний фунгіцид широкого спектра дії класу триазолів. Він входить до складу багатьох сучасних препаратів для боротьби з фрітопатогенами. Його широко застосовують у сільському господарстві світу та України зокрема. Попри свої гепатотоксичні характеристики, даний фрунгіцид порушує гематологічні параметри крові.

Мета дослідження - вивчити вплив генеричного триазольного фрунгіциду епоксиконазолу 95 \% на гематологічні та цитохімічні показники перифреричної крові щурів Wistar Hannover за умов гострого експерименту.

Meтоди дослідження. Дослідження проведено на 10 статевозрілих щурах-самцях Wistar Han, поділених на контрольну (0 мг/кг) та експериментальну групи. Тваринам експериментальної групи було введено токсичну дозу 1580 мг/ке маси тіла (1/2 від лД50) одноразово внутрішньошлунково через зонд. Периферичну кров досліджували на 0 ma 1, 3, 7 і 14 доби після експозиції. Вивчали гематологічні показники: кількісний вміст еритроцитів, концентрацію гемоглобіну, рівень гематокриту, еритроцитарні індекси (середній об'єм еритроцита, середній вміст гемоглобіну в одному еритроциті, середню концентрацію гемоглобіну в одному еритроциті), кількість лейкоцитів та тромбоцитів. Гемограму з оцінкою морфологічних змін клітин крові та відсоткового співвідношення різних видів лейкоцитів досліджували в мазках перифреричної крові. Цитохімічний статус лейкоцитів оцінювали на основі визначення фрерментативної активності нафотол-AS-D-хлорацетатестерази в нейтрофрілах, сукцинатдегідрогенази та кислої фросфратази в лімфроцитах.

Результати й обговорення. Еритроцитоз у відповідь на інтоксикацію пестицидом зі зменшенням середньої концентрації гемоглобіну в одному еритроциті, зниження концентрації гемоглобіну до кінця експерименту на фроні активної поліхромазії свідчать про анемізуючу дію епоксиконазолу. Реактивний нейтрофрільоз, стимуляцію лімфоцитопоезу та моноцитопоезу, появу в периферичній крові макрофрагів, збільшення активності нафтол-AS-D-хлорацетатестерази, сукцинатдегідрогенази та кислої фросфратази розцінено як компенсаторні механізми. Відмічено зворотні кількісні зміни у співвідношенні субпопуляцій лімфроцитів за активністю кислої фросфратази.

Висновок. Аналіз результатів дослідження гематотоксичної дії генеричного триазольного фрунгіциду епоксиконазолу 95 \% за умов гострого експерименту на щурах-самцях Wistar Hannover показав розвиток прихованої анемії, що проявилась у пізній термін дослідження; активізацію моноцитопоезу; збільшення макрофрагів у судинному руслі; зміни імунної відповіді організму і появу атипових нормоцитів та лімороцитів з аномаліями ядер.

КЛЮЧОВІ СЛОВА: епоксиконазол; гематотоксичність; анемія; сукцинатдегідрогеназа; кисла фросфратаза; нафтол-AS-D-хлорацетатестераза; макрофраги; “хвостаті” лімфоцити.

ВСТУП. Епоксиконазол (ЕПО) - високоефективний фрунгіцид широкого спектра дії класу триазолів. Він входить до складу багатьох сучасних препаратів для боротьби з фрітопатогенами: збудниками борошнистої роси, іржі, плямистостей колоса і листя зернових культур [1]. Його активно застосовують у сільському господарстві світу та України зокрема. Згідно з висновками регуляторних органів (EPA US, EFSA Europe), ключовим органом-мішенню є печінка. Але попри ○ Т. В. Усенко, В. Г. Шуляк, 2018. свої гепатотоксичні характеристики, даний фрунгіцид порушує гематологічні параметри крові [2]. Літературні дані щодо негативного впливу епоксиконазолу на систему крові не численні. Деякі роботи засвідчують вплив ЕПО на червону кров, що проявляється зниженням кількості еритроцитів, концентрації гемоглобіну, гематокриту, середньої концентрації гемоглобіну в одному еритроциті та тромбоцитів у щурів-самиць $[3,4]$. За результатами проведених токсикокінетичних досліджень, найбільшу концентрацію абсорбо- 
ваного після надходження в організм ЕПО відмічено саме в еритроцитах перисреричної крові, а період напіввиведення Т1/2 для ЕПО досить високий - 168 год (7 діб) [5]. 3 огляду на такі особливості даної тестової субстанції, було важливо оцінити особливості гематотоксичної дії ЕПО, вплив на червону та білу кров, а також дослідити цитохімічний статус лейкоцитів за умов моделювання гострого отруєння пестицидом.

Мета дослідження - вивчити вплив генеричного триазольного фунгіциду епоксиконазолу $95 \%$ на гематологічні та цитохімічні показники периферичної крові щурів Wistar Hannover за умов гострого експерименту.

МЕТОДИ ДОСЛІДЖЕННЯ. Лабораторних щурів-самців Wistar Han було отримано з розплідника Наукового токсикологічного центру імені академіка Л. І. Медведя МОЗ України. Вони мали SPF-статус, що підтверджувалося відповідними сертиорікатами. Щурів утримували в окремих клітках по 5 тварин у кожній у контрольованих умовах конвенційного віварію (відносна вологість - 30-70\%, температура - 19-23 ${ }^{\circ} \mathrm{C}$ автоматична 12-годинна система освітлення "день - ніч"). Корм (“Altramin", Німеччина) та вода (фрільтрована зворотним осмосом та дезінфрікована шляхом ультрафріолетового опромінення) надавались ad libitum. Усі маніпуляції зі щурами виконували відповідно до положень Комісії 3 етики медичних та біологічних досліджень Наукового токсикологічного центру імені академіка Л. І. Медведя МО3 України та Європейської конвенції про захист хребетних тварин, що використовуються для дослідних та інших наукових цілей (Страсбург, 1986) [6, 7]. На всіх етапах гематологічних та цитохімічних досліджень маніпуляції було проведено з дотриманням стандартних операційних процедур центру, відповідно до рекомендацій Належної лабораторної практики (GLP) [8].

Після періоду акліматизації тварин до умов конвенційного віварію та перед початком експерименту в них було оцінено вхідні гематологічні показники (нульовий день досліджень) і ссрормовано групи, що вірогідно не відрізнялись одна від одної. Дослідження проведено на статевозрілих щурах-самцях Wistar Han масою тіла 280-300 г, поділених на 2 групи (по 5 тварин у кожній): 1-ша - контрольна; 2-га - експериментальна.

За даними Агенції із захисту навколишнього середовища США (EPAUS), напівлетальна доза (ЛД50) епоксиконазолу для самців становить 3160 мг/кг маси тіла [9]. Щурам 2-ї групи одноразово внутрішньошлунково через зонд було введено токсичну дозу 1580 мг/кг маси тіла - 1/2 від ЛД50. Тварини 1-ї групи отримували розчинник (вода з емульгатором ОП-10 в концентрації $0,002 \%)$.

Перифреричну кров досліджували на 0 та 1, 3, 7 і 14 доби після експозиції епоксиконазолом [10]. Вивчали гематологічні показники: кількісний вміст еритроцитів, концентрацію гемоглобіну, рівень гематокриту, еритроцитарні індекси (середній об'єм еритроцита, середній вміст гемоглобіну в одному еритроциті, середню концентрацію гемоглобіну в одному еритроциті), кількість лейкоцитів та тромбоцитів. Визначали їх за допомогою ветеринарного автоматичного гематологічного аналізатора "Micros ABC" ("Horiba Diagnostics", France). Гемограму з оцінкою морфрологічних змін клітин крові та відсоткового співвідношення різних видів лейкоцитів досліджували в мазках перисреричної крові, забарвлених за Паппенгеймом-Крюковим [11]. Цитохімічний статус лейкоцитів оцінювали на основі визначення активності таких ферментів: насртол-AS-D-хлорацетатестерази в нейтрофрілах за методом Молоні та співавт., сукцинатдегідрогенази в лімфоцитах за методом Нарцисова, кислої фоосфатази в лімфроцитах реакцією одночасного азосполучення за методом Голдберга і Барка $[12,13]$. Результати аналізу 100 лейкоцитів у мазку виражали у вигляді середнього цитохімічного коефіцієнта, використовуючи принцип Астальді [12].

Отримані дані піддавали статистичній обробці. Результати аналізували за допомогою 2-way ANOVA та t-критерію Стьюдента.

\section{РЕЗУЛЬТАТИ Й ОБГОВОРЕННЯ.}

\section{Гематологічні дослідження.}

Червона кров. У результаті дослідження гематологічних показників периферичної крові через добу після введення ЕПО у відповідь на гостру інтоксикацію в щурів експериментальної групи (табл. 1) встановлено вірогідне підвищення кількості еритроцитів на 7,7 \% $(p \leq 0,05)$ та, відповідно, достовірне зниження середньої концентрації гемоглобіну в одному еритроциті на 2,4 \% відносно контролю. Зменшення індексу середньої концентрації гемоглобіну в одному еритроциті на 4,5 \% залишалось достовірним і на 3 післяекспозиційну добу (ПЕД), зберігалась тенденція до еритроцитозу. Згідно з літературними даними, ЕПО може інгібувати зв'язування заліза під час біосинтезу гему: молекула азолу діє як неконкурентний інгібітор [3]. Тому зниження середньої концентрації гемоглобіну в одному еритроциті вказує на можливі порушення процесів гемоглобіноутворення в клітинах-попередниках еритроцитів у кістковому мозку. На 14 ПЕД 
Таблиця 1 - Гематологічні показники периферичної крові щурів Wistar Han

\begin{tabular}{|c|c|c|c|}
\hline Показник & $\begin{array}{c}\text { Термін } \\
\text { дослідження }\end{array}$ & 1-ша група (контроль) & 2-га група (ЕПО) \\
\hline \multirow[t]{5}{*}{ Еритроцити, 1012/л } & 0 & $8,81 \pm 0,26$ & $9,03 \pm 0,27$ \\
\hline & 1 & $7,84 \pm 0,17$ & $8,44 \pm 0,18^{*}$ \\
\hline & 3 & $8,49 \pm 0,25$ & $9,26 \pm 0,34$ \\
\hline & 7 & $7,87 \pm 0,24$ & $8,14 \pm 0,20$ \\
\hline & 14 & $8,13 \pm 0,17$ & $8,15 \pm 0,45$ \\
\hline \multirow{5}{*}{ Гемоглобін, г/л } & 0 & $172,80 \pm 6,85$ & $176,20 \pm 6,58$ \\
\hline & 1 & $174,60 \pm 5,16$ & $177,40 \pm 4,26$ \\
\hline & 3 & $183,00 \pm 1,47$ & $188,40 \pm 6,38$ \\
\hline & 7 & $169,25 \pm 8,41$ & $170,75 \pm 3,20$ \\
\hline & 14 & $169,75 \pm 1,65$ & $165,60 \pm 8,80$ \\
\hline \multirow{5}{*}{ Лейкоцити, 10\%/л } & 0 & $11,58 \pm 2,58$ & $11,54 \pm 0,94$ \\
\hline & 1 & $15,46 \pm 1,49$ & $14,82 \pm 1,24$ \\
\hline & 3 & $15,43 \pm 1,13$ & $20,82 \pm 3,89$ \\
\hline & 7 & $19,05 \pm 2,39$ & $18,53 \pm 1,51$ \\
\hline & 14 & $15,35 \pm 0,92$ & $14,96 \pm 1,00$ \\
\hline \multirow[t]{5}{*}{ Гематокрит, \% } & 0 & $49,48 \pm 1,71$ & $50,24 \pm 1,15$ \\
\hline & 1 & $45,18 \pm 1,48$ & $47,10 \pm 1,20$ \\
\hline & 3 & $48,30 \pm 0,77$ & $52,04 \pm 2,14$ \\
\hline & 7 & $44,60 \pm 2,06$ & $45,68 \pm 0,37$ \\
\hline & 14 & $45,88 \pm 0,68$ & $44,62 \pm 2,50$ \\
\hline \multirow[t]{5}{*}{ Тромбоцити, 10\%/л } & 0 & $555,00 \pm 125,71$ & $674,20 \pm 125,72$ \\
\hline & 1 & $646,40 \pm 47,12$ & $702,60 \pm 59,66$ \\
\hline & 3 & $714,00 \pm 90,14$ & $547,00 \pm 78,10$ \\
\hline & 7 & $614,00 \pm 86,00$ & $456,00 \pm 60,62$ \\
\hline & 14 & $494,50 \pm 59,77$ & $616,20 \pm 74,38$ \\
\hline \multirow{5}{*}{$\begin{array}{l}\text { Середній об'єм } \\
\text { еритроцитів, фрл }\end{array}$} & 0 & $56,20 \pm 2,04$ & $55,60 \pm 1,50$ \\
\hline & 1 & $57,60 \pm 1,36$ & $55,80 \pm 0,80$ \\
\hline & 3 & $56,75 \pm 1,11$ & $56,00 \pm 0,95$ \\
\hline & 7 & $56,50 \pm 0,96$ & $56,25 \pm 1,03$ \\
\hline & 14 & $56,50 \pm 0,96$ & $54,80 \pm 0,66$ \\
\hline \multirow{5}{*}{$\begin{array}{l}\text { Середній вміст } \\
\text { гемоглобіну в одному } \\
\text { еритроциті, пг }\end{array}$} & 0 & $19,64 \pm 0,82$ & $19,52 \pm 0,90$ \\
\hline & 1 & $22,26 \pm 0,44$ & $21,06 \pm 0,32$ \\
\hline & 3 & $21,63 \pm 0,63$ & $20,34 \pm 0,45$ \\
\hline & 7 & $21,53 \pm 0,65$ & $21,05 \pm 0,66$ \\
\hline & 14 & $20,88 \pm 0,47$ & $20,34 \pm 0,38$ \\
\hline \multirow{5}{*}{$\begin{array}{l}\text { Середня концентрація } \\
\text { гемоглобіну в одному } \\
\text { еритроциті, г/л }\end{array}$} & 0 & $349,20 \pm 2,04$ & $350,60 \pm 5,99$ \\
\hline & 1 & $386,60 \pm 3,08$ & $377,20 \pm 0,58$ \\
\hline & 3 & $379,00 \pm 5,12$ & $362,00 \pm 4,57$ \\
\hline & 7 & $379,75 \pm 6,54$ & $374,25 \pm 7,49$ \\
\hline & 14 & $370,00 \pm 3,49$ & $371,40 \pm 4,88$ \\
\hline
\end{tabular}

у щурів відмічено зниження концентрації гемоглобіну на 2,4 \% та зменшення середнього об'єму еритроцитів на 2,6 \%, що є ознакою анемізуючої дії епоксиконазолу. На підтвердження цього фракту при аналізі морфології еритроцитів у мазках крові встановлено вірогідне підвищення кількості поліхроматофрільних еритроцитів: у 15 разів - на 1 ПЕД, у 4 рази - на 14 ПЕД. Тенденцію до поліхромазії було відмічено на 3 та 7 ПЕД експерименту.

У мазках периферичної крові на 1 та 14 ПЕД було виявлено поодинокі поліхроматофільні нормоцити (ПХН) кісткового мозку. Серед нормальних ПХН (рис. 1) спостерігали атипові бінуклеарні ПХН (рис. 2, 3), ПХН із каріорексисом та порушеннями енуклеації ядра. Поява таких клітин вказує на порушення процесів дозрівання та поділу клітин-попередників еритроцитів у кістковому мозку, зміну або втрату їх фрункцій [14].

Впродовж усіх термінів дослідження кількісні зміни тромбоцитів були недостовірними та в межах фрізіологічних коливань.

Біла кров. На 1 ПЕД зміни білої крові (табл. 2) проявлялись відносним нейтрофільозом: вірогідно збільшувалась (на 72 \%) загальна кількість нейтрофрілів за рахунок сегментоядерних фрорм (на $68 \%$ ). Інших змін у лейкоцитарній фрормулі не встановлено. При дослідженні морфології лейкоцитів виявлено велику кількість зруйнованих клітин нейтрофрільного ряду. Цитолізовані клітини мали деструктивну оболонку (або вона зовсім була відсутня), без цитоплазми, ядра втрачали свою структуру, були розмитими та 
Таблиця 2 - Відносний (лейкограма) та абсолютний вміст лейкоцитів перифреричної крові щурів Wistar Han

\begin{tabular}{|c|c|c|c|c|c|}
\hline \multirow[b]{2}{*}{ Показник } & \multirow[b]{2}{*}{ ПЕД } & \multicolumn{2}{|c|}{ ІЛейкограма, \% } & \multicolumn{2}{|c|}{ Абсолютний вміст, 10\%/л } \\
\hline & & $\begin{array}{c}\text { 1-ша група } \\
\text { (0 мг/кг) }\end{array}$ & $\begin{array}{c}\text { 2-га група } \\
\text { (1580 мг/кг) }\end{array}$ & $\begin{array}{c}\text { 1-ша група } \\
\text { (0 мг/кг) }\end{array}$ & $\begin{array}{c}\text { 2-га група } \\
\text { (1580 мг/кг) }\end{array}$ \\
\hline \multirow{4}{*}{ Метамієлоцит } & 1 & - & - & - & - \\
\hline & 3 & - & - & - & - \\
\hline & 7 & $1,00 \pm 0,00$ & $1,00 \pm 0,00$ & $0,07 \pm 0,06$ & $0,03 \pm 0,03$ \\
\hline & 14 & - & $1,00 \pm 0,00$ & - & $0,03 \pm 0,03$ \\
\hline \multirow{4}{*}{$\begin{array}{l}\text { Паличкоядерний } \\
\text { нейтрофріл }\end{array}$} & 1 & - & $1,75 \pm 0,15$ & $0,00 \pm 0,00$ & $0,06 \pm 0,03$ \\
\hline & 3 & $1,00 \pm 0,00$ & $1,67 \pm 0,43$ & $0,09 \pm 0,04$ & $0,18 \pm 0,12$ \\
\hline & 7 & $1,50 \pm 0,21$ & $1,50 \pm 0,22$ & $0,27 \pm 0,03$ & $0,11 \pm 0,08$ \\
\hline & 14 & $2,33 \pm 0,64$ & $2,33 \pm 0,64$ & $0,27 \pm 0,12$ & $0,23 \pm 0,14$ \\
\hline \multirow{4}{*}{$\begin{array}{l}\text { Сегментоядерний } \\
\text { нейтрофріл }\end{array}$} & 1 & $10,00 \pm 1,72$ & $16,80 \pm 2,58$ & $1,54 \pm 0,27$ & $2,46 \pm 0,44$ \\
\hline & 3 & $11,25 \pm 2,15$ & $12,50 \pm 1,93$ & $1,66 \pm 0,21$ & $1,70 \pm 0,57$ \\
\hline & 7 & $11,25 \pm 0,86$ & $9,50 \pm 1,29$ & $2,10 \pm 0,21$ & $1,45 \pm 0,53$ \\
\hline & 14 & $15,75 \pm 1,29$ & $17,60 \pm 3,00$ & $2,40 \pm 0,16$ & $2,71 \pm 0,66$ \\
\hline \multirow[t]{4}{*}{ Усього нейтрофрілів } & 1 & $10,00 \pm 1,72$ & $17,20 \pm 2,36$ & $1,54 \pm 0,27$ & $2,52 \pm 0,40$ \\
\hline & 3 & $11,75 \pm 1,93$ & $13,75 \pm 2,15$ & $1,75 \pm 0,17$ & $1,88 \pm 0,69$ \\
\hline & 7 & $13,00 \pm 1,07$ & $10,50 \pm 1,07$ & $2,44 \pm 0,28$ & $1,59 \pm 0,53$ \\
\hline & 14 & $17,50 \pm 1,07$ & $19,20 \pm 3,43$ & $2,67 \pm 0,17$ & $2,97 \pm 0,73$ \\
\hline \multirow[t]{4}{*}{ Еозинофріл } & 1 & $1,50 \pm 0,21$ & $1,33 \pm 0,22$ & $0,11 \pm 0,06$ & $0,11 \pm 0,06$ \\
\hline & 3 & - & $2,33 \pm 0,22$ & - & $0,23 \pm 0,09$ \\
\hline & 7 & $1,00 \pm 0,00$ & $1,33 \pm 0,22$ & $0,15 \pm 0,06$ & $0,15 \pm 0,09$ \\
\hline & 14 & $2,50 \pm 0,64$ & $2,00 \pm 0,43$ & $0,21 \pm 0,15$ & $0,12 \pm 0,10$ \\
\hline \multirow[t]{4}{*}{ Базофріл } & 1 & - & $1,00 \pm 0,00$ & - & $0,05 \pm 0,03$ \\
\hline & 3 & - & - & - & - \\
\hline & 7 & - & $1,00 \pm 0,00$ & - & $0,04 \pm 0,04$ \\
\hline & 14 & $1,00 \pm 0,00$ & $1,00 \pm 0,00$ & $0,03 \pm 0,03$ & $0,04 \pm 0,04$ \\
\hline \multirow[t]{4}{*}{ Моноцит } & 1 & $9,50 \pm 0,64$ & $10,40 \pm 1,07$ & $1,44 \pm 0,27$ & $1,54 \pm 0,23$ \\
\hline & 3 & $6,25 \pm 0,85$ & $25,75 \pm 2,58$ & $0,96 \pm 0,14$ & $3,56 \pm 1,28$ \\
\hline & 7 & $10,75 \pm 2,15$ & $14,00 \pm 2,58$ & $2,02 \pm 0,34$ & $2,11 \pm 0,99$ \\
\hline & 14 & $13,75 \pm 1,50$ & $14,80 \pm 1,72$ & $2,11 \pm 0,26$ & $2,21 \pm 0,29$ \\
\hline \multirow[t]{4}{*}{ Лімфоцит } & 1 & $79,75 \pm 2,79$ & $71,20 \pm 3,00$ & $12,17 \pm 1,42$ & $10,64 \pm 1,34$ \\
\hline & 3 & $81,50 \pm 2,36$ & $58,75 \pm 2,58$ & $12,62 \pm 1,14$ & $7,95 \pm 2,28$ \\
\hline & 7 & $75,25 \pm 2,15$ & $74,25 \pm 2,58$ & $14,41 \pm 2,05$ & $10,94 \pm 3,38$ \\
\hline & 14 & $66,75 \pm 0,21$ & $64,80 \pm 3,65$ & $10,24 \pm 0,55$ & $9,59 \pm 0,46$ \\
\hline
\end{tabular}

нечітко окресленими. Деякі нейтрофрільні гранулоцити являли собою лише залишки ядер та зернистості. Достовірно підвищувалась кількість гіперсегментованих нейтрофрілів та нейтрофрілів з ознаками дегенеративних змін ядер, такими, як: оррагментація, хроматиноліз, конденсація

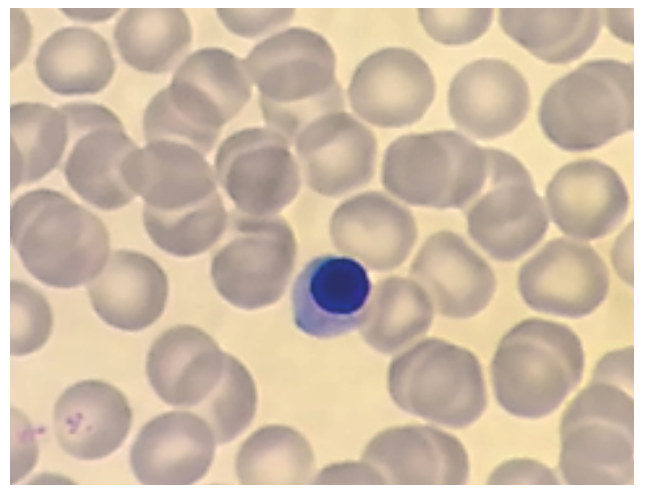

Рис. 1. Поліхроматофрільний нормоцит у периферичній крові щурів Wistar Han на 1 добу після експозиції епоксиконазолом; забарвлення за Паппенгеймом-Крюковим, $10 \times 100$. хроматину, вакуолізація. Часто ці дегенерації комбінувались між собою. На нашу думку, нейтрофрільоз у перифреричній крові мав реактивний характер та був зумовлений активацією судинного пристінкового (маргінального) пулу лейкоцитів, і його можна розцінити як компенсаторний

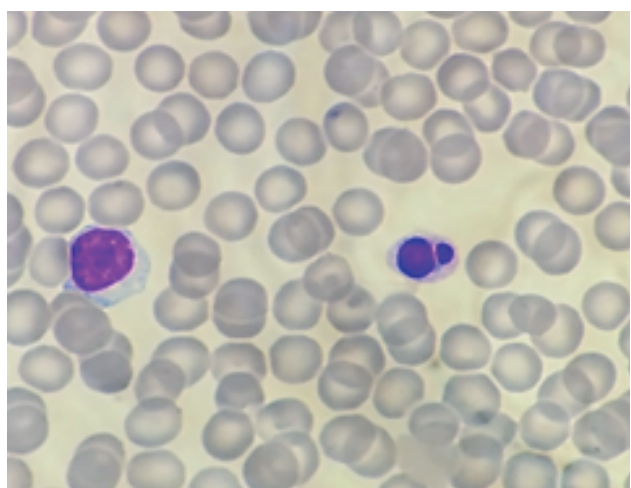

Рис. 2. Лімфоцит (зліва) та атиповий бінуклеарний поліхроматофільний нормоцит (справа) в периферичній крові щурів Wistar Han на 14 добу після експозиції епоксиконазолом; забарвлення за Паппенгеймом-Крюковим, $10 \times 100$. 


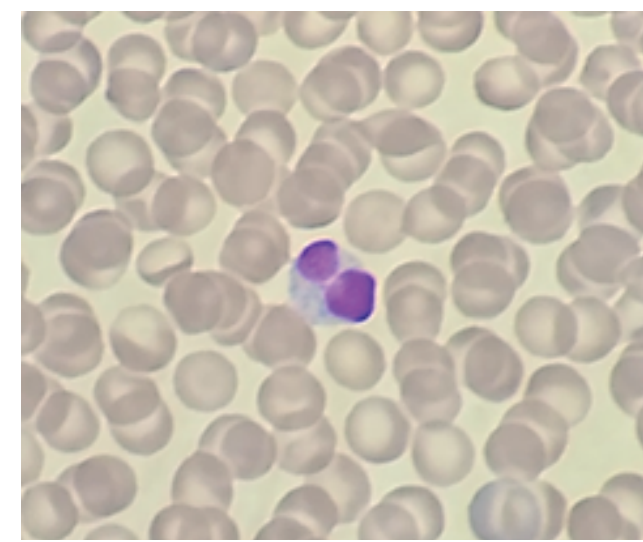

Рис. 3. Бінуклеарний поліхроматофільний нормоцит у стадії мітозу в периферичній крові щурів Wistar Han на 14 добу після експозиції епоксиконазолом; забарвлення за Паппенгеймом-Крюковим, 10×100.

механізм у відповідь на інтоксикацію ЕПО в цей термін дослідження.

До 3 ПЕД загальна кількість лейкоцитів у щурів експериментальної групи була підвищеною на $35 \%$ відносно контролю. Відмічено нормалізацію вмісту клітин нейтрофрільного ряду: достовірних розбіжностей не встановлено. У цей термін зафріксовано відносну і тенденцію до абсолютної лімфоцитопенії: вірогідне зниження кількості лімфоцитів на 28 \% відносно показників контрольної групи самців. Зростав вміст пролімсроцитів $(2,09 \pm 0,15$, в контролі-0,88 $\pm 0,03)$ та плазматичних клітин $(0,49 \pm 0,05$, в контролі - 0). Щодо морфологічних особливостей лімсроцитів, то вірогідно підвищувалась кількість атипових "хвостатих" лімфоцитів з випинаннями (виростами) ядра в цитоплазматичний простір (рис. 4, 5). Такі морфологічні особливості клітин можуть вказувати на порушення ампліфрікації ДНК в ядрі лімсоцита під час мітозу або пошкодження ДНК-репаративних механізмів у клітині [15-17].

Найбільш значимими в цей термін були зміни моноцитарного ряду клітин. У лейкограмі зафріксовано відносний моноцитоз: збільшення кількості моноцитів у 4 рази відносно контролю (табл. 2). Окрім того, виявлено зміни в морфології моноцитів: хроматиноліз, частковий каріоліз, вакуолізацію ядра та цитоплазми. У мазках відмічено велику кількість зруйнованих клітин цього виду. На фроні значного моноцитозу в судинному руслі циркулювала велика кількість макрофрагів у стадії активного фрагоцитозу $(9,25 \pm 1,3$, В контролі - 0). Вони характеризувались поліморфрізмом розмірів, ступенем зрілості та ознаками деструкції. Переважали молоді клітини: ядерний хроматин ніжної структури, ядра містили ядерця. У цитоплазмі були наявні мікропухирці та вакуолі, а також фррагменти деструктивних ядерних та клітинних структур. Траплялись мак-

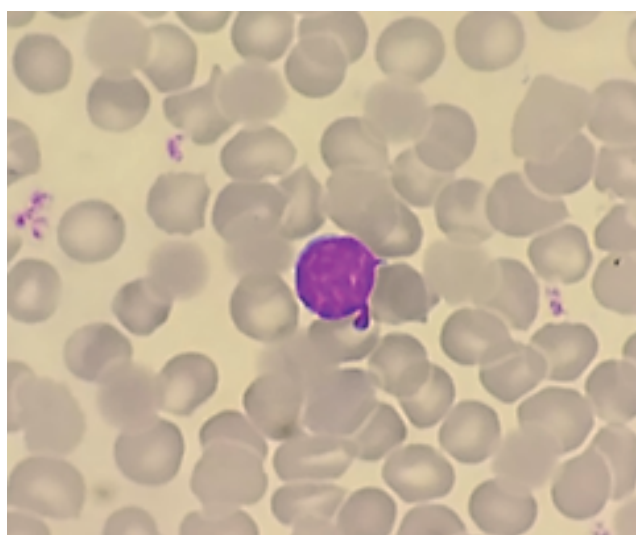

Рис. 4. Атиповий “хвостатий” лімфоцит периферичної крові щурів Wistar Han на 3 добу після експозиції епоксиконазолом; забарвлення за Паппенгеймом-Крюковим, $10 \times 100$.

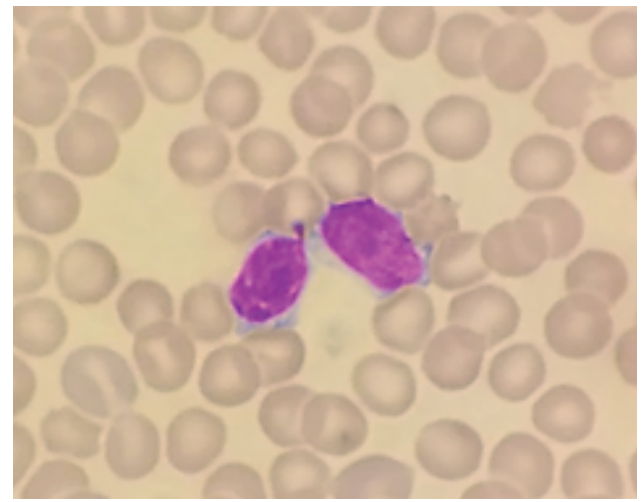

Рис. 5. Атиповий "хвостатий” лімфоцит та середній лімфоцит периферичної крові щурів Wistar Han на 3 добу після експозиції епоксиконазолом; забарвлення за Паппенгеймом-Крюковим, 10х100.

рофаги із захопленими еритроцитами. Серед зрілих моноцитів було виявлено молоді форми клітин: монобласти $(0,17 \pm 0,01$, в контролі - 0$)$ та промоноцити $(0,52 \pm 0,02$, в контролі - 0). Активація моноцитарного ряду, на нашу думку, пов'язана з підвищеною потребою організму в очищенні крові та, можливо, інших тканин організму від зруйнованих клітин і детриту.

На 7 ПЕД загальний вміст лейкоцитів у перифреричній крові, кількість нейтрофрілів та лімфоцитів у тварин експериментальної групи достовірно не відрізнялись від значень контрольної. Продовжувала зростати (у 2,5 раза) кількість плазматичних клітин. Усе ще залишалась підвищеною (на 30 \%) кількість зрілих моноцитів. Окрім того, відмічено вірогідне збільшення зруйнованих клітин - форм лейколізу.

На 14 ПЕД жодних вірогідних змін білої крові (загальна кількість лейкоцитів, показники лейкоцитарної фрормули) не спостерігали. Разом із тим, у периореричну кров продовжували надходити пролімсоцити (у 2,5 раза) та промоноцити (у 4 рази більше, ніж у контрольній групі). 


\section{Цитохімічні дослідження.}

Результати дослідження цитохімічного статусу лейкоцитів наведено на рисунку 6 .

Насртол-AS-D-хлорацетатестераза - специфрічний орермент нейтрофрілів, міститься в цитоплазматичних гранулах (первинних лізосомах), забезпечує протеолітичну та фрагоцитарну фуннкції. Даний фермент є маркерним для нейтрофрільного ряду клітин, його активність знижується в міру дозрівання клітин [13]. Так, на 7 ПЕД встановлено достовірне підвищення його активності в нейтрофрілах (на $66 \%$ ) без наявних змін їх загальної кількості. Такий стан ферментативних систем вказує на активізацію адаптивних механізмів у клітинах крові та появу в периоеричній крові фрункціонально активних нейтрофрілів. У деяких наукових роботах описано захисну функкцію даного фрерменту, який є каталізатором гідролізу ксенобіотичних сполук або зв'язування значної частини метаболітів, послаблюючи, таким чином, їх токсичну дію на організм [18].

Сукцинатдегідрогеназа як один із ключових ферментів циклу трикарбонових кислот та дихального ланцюга $€$ показником енергообміну в мітохондріях. Активність її знижується в міру дозрівання клітин [13, 19]. На 7 ПЕД встановлено достовірне підвищення активності сукцинатдегідрогенази в лімфоцитах (на $5 \%$ ). Це можна пояснити виходом у периферичну кров молодих форм пролімфоцитів на 3 ПЕД, які до 7 доби експерименту не втратили своєї фрункціональної активності, та зростанням кількості плазматичних клітин у перифреричній крові на 7 ПЕД.

Кисла фоосфатаза локалізується в лізосомах лімсооцитів. Активність ії вірогідно зростає в щурів експериментальної групи на 1 ПЕД (на 35 \%) та 3 ПЕД (на 40 \%). Це вказує на підвищення катаболічних процесів у клітинах крові.

Метод визначення кислої фоосфатази за допомогою реакції азосполучення дозволяє не лише оцінити функціональний стан лізосомального апарату лейкоцитів, а й провести ідентифрікацію Т-, В-, нульових лімсоцитів. Нульові лімсроцити, або NK-клітини, - це особлива резервна популяція, молоді, функціонально активні клітини, які за необхідності можуть диференціюватись У Т- чи В-лімфоцити. Основна їх фуннкція знешкодження власних клітин організму, в яких відбулись критичні для клітини зміни. Також вони можуть перетворюватись у моноцити, фрібробласти, макрофраги, тобто в клітини, які беруть участь у регенераційних процесах організму [20-23].

Аналіз результатів досліджень кислої фооссратази після впливу ЕПО на особливості цитохімічної відповіді різних морфологічних груп лімсроцитів (рис. 7) показав зниження кількості В-лімфоцитів (на 50 \%) та вірогідне підвищення
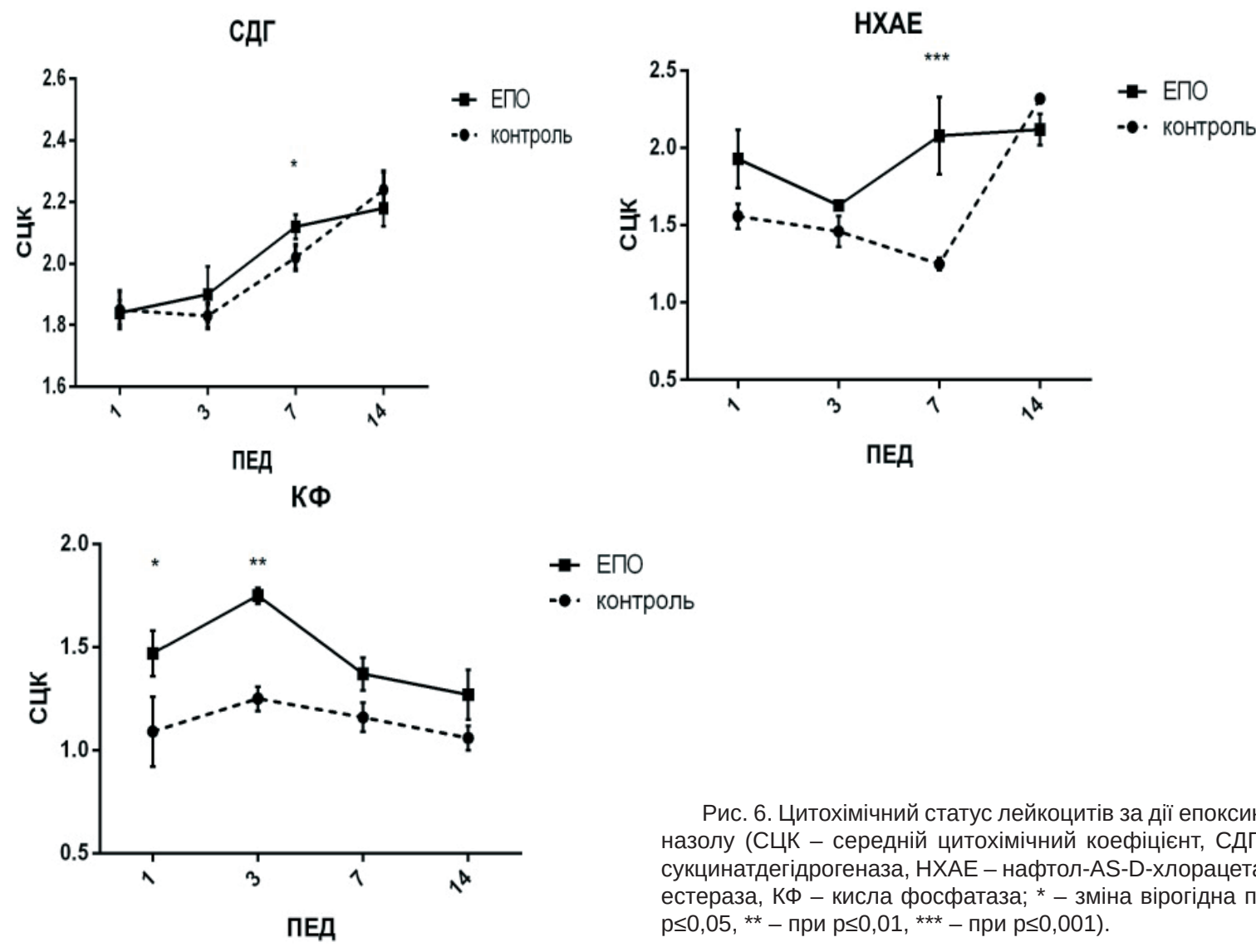

Рис. 6. Цитохімічний статус лейкоцитів за дії епоксиконазолу (СЦК - середній цитохімічний коефріцієнт, СДГ сукцинатдегідрогеназа, HXAE - нафтол-AS-D-хлорацетатестераза, КФ - кисла фоосфатаза; * - зміна вірогідна при $\mathrm{p} \leq 0,05,{ }^{* *}-$ при $\left.\mathrm{p} \leq 0,01,{ }^{* \star *}-п р и \mathrm{p} \leq 0,001\right)$. 
Розподіл В-лімфоцитів за активністю КФ

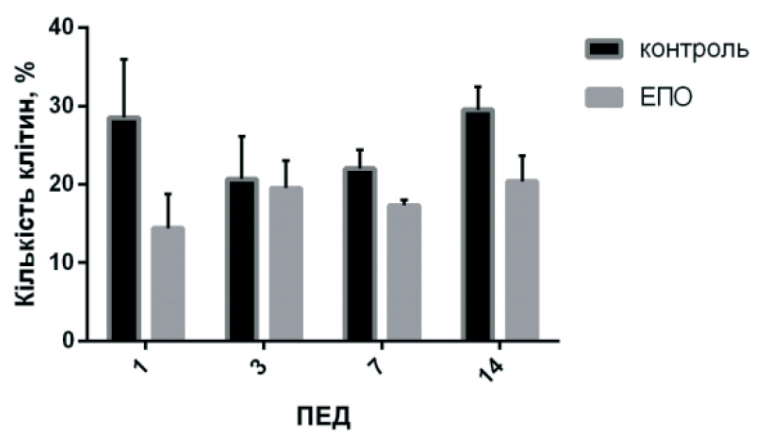

Розподіл Т-лімфоцитів за активністю КФ

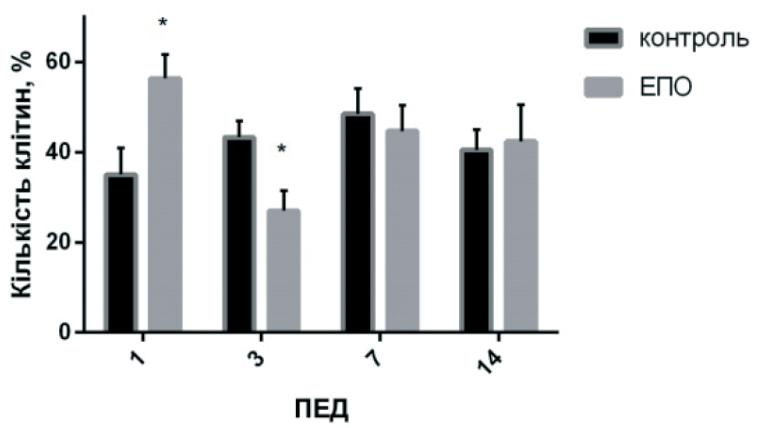

Розподіл нульових лімфоцитів за активністю КФ

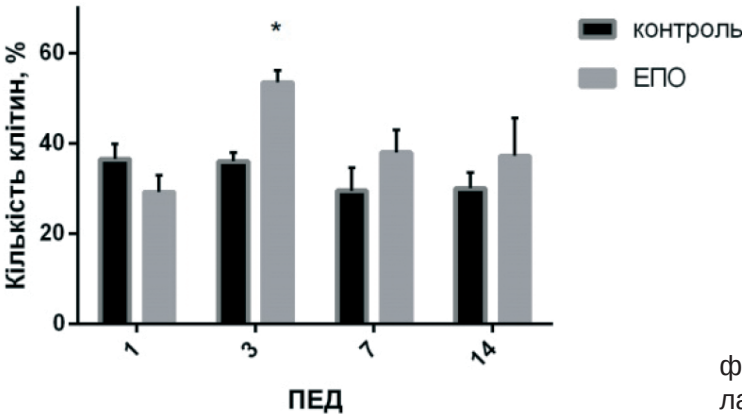

Т-лімсроцитів (на 61 \%) на 1 ПЕД. Це може свідчити про активізацію специфічного клітинного імунітету. До 3 ПЕД кількість Т-лімфоццитів вірогідно зменшилась (на 54 \%), а кількість нульових лімфоцитів достовірно збільшилась (на 49 \%). На нашу думку, підвищення NK-клітин можна пояснити розвитком імуномодулюючої відповіді організму щурів після впливу епоксиконазолу. На 7 та 14 ПЕД співвідношення різних субпопуляцій лімфоцитів у тварин експериментальної групи вірогідно не відрізнялось від значень контролю.

ВИСНОВКИ. Аналіз результатів дослідження гематотоксичної дії генеричного триазольного фуунгіциду епоксиконазолу 95 \% за умов гострого експерименту на щурах-самцях Wistar Hannover показав розвиток прихованої анемії, що проявилась у пізній термін дослідження; активізацію моноцитопоезу; збільшення макрофрагів у судинному руслі; зміни імунної відповіді організму і появу атипових нормоцитів та лімсоцитів з аномаліями ядер.

Епоксиконазол призводив до змін червоної крові, характерних для анемії: зниження концентрації гемоглобіну в динаміці та середнього об'єму еритроцитів. Поява ПХН на фоні активної поліхромазії свідчила про прихований її перебіг.

3 боку білої крові відмічено стимуляцію моноцитопоезу та лімсроцитопоезу в кістковому мозку. При цьому спостерігали появу в перисреричній крові молодих форм - монобластів, про-
Рис. 7. Розподіл лімфоцитів за активністю кислої фоосфатази в лімфоцитах периферичної крові щурів (КФ - кисла фоосратаза; * - зміна вірогідна при $p \leq 0,05$ ).

моноцитів та пролімфоцитів. Вихід у перифреричну кров попередників зрілих клітин мав компенсаторний характер у відповідь на дію епоксиконазолу.

Наявність активних макрофрагів у судинному руслі мала захисний характер.

Поява атипових "хвостатих" лімфоцитів та поліхроматофрільних нормоцитів кісткового мозку в перисреричній крові може свідчити про вплив епоксиконазолу на процеси поділу й дозрівання клітин, що потребує подальших спеціалізованих досліджень.

Зміни цитохімічного статусу лімфроцитів вказують на активізацію адаптаційних механізмів в організмі щурів:

- ЕПО не порушував протеолітичних та фрагоцитарних фрункцій нейтрофрілів; збільшення активності нафтол-AS-D-хлорацетатестерази можна розцінити як компенсаторний механізм у клітинах нейтрофрільного ряду;

- ЕПО не порушував метаболічних процесів у мітохондріях лімфоцитів; активність сукцинатдегідрогенази на 7 добу експерименту підвищувалась за рахунок виходу в перисреричну кров пролімсоццитів, які не втратили своєї фрункціональної активності;

- ЕПО впливав на імунний статус організму щурів; було відмічено зворотні кількісні зміни у співвідношенні Т-, В- та нульових лімфоцитів.

Перспективи подальших досліджень. Подальші поглиблені дослідження механізмів гематотоксичної дії генеричного триазольного 
фунгіциду епоксиконазолу вимагають комплексного аналізу гематологічних та цитохімічних показників, оцінки морорологічних змін клітин крові, дослідження процесів поділу і дозрівання клітин у кістковому мозку та селезінці й дозволять розмежувати адаптаційні процеси та розвиток можливих патологічних станів системи крові в організмі щурів.

\section{СПИСОК ЛІТЕРАТУРИ}

1. Практичне значення та застосування похідних 1,2,4-тріазолу : монографрія [Електронний ресурс] / [А. Г. Каплаушенко, Е. І. Книш, О. І. Панасенко та ін.]. Запоріжжя : ЗДМУ, 2016. - 187 с. - Режим доступу : http://dspace.zsmu.edu.ua/handle/ 123456789/4902].

2. Peer review of the pesticide risk assessment of the active substance epoxiconazole // EFSA Journal. 2015. - No. 13 (6). - P. 4123.

3. Human and ecological risk assessment of a crop protection chemical: a case study with the azole fungicide epoxiconazole / J. E. Chambers, H. Greim, R. J. Kendall [et al.] // Critical Reviews in Toxicology. - 2014. - 44, No. 2. - P. 176-210.

4. Schmidt F. Combination effects of azole fungicides in male rats in a broad dose range / F. Schmidt, P. MarxStoelting // Toxicology. - 2016. - No. 355. - P. 54-63.

5. EPA MEMORANDUM January 24, 2001 Epoxiconazole - Report of the Cancer Assessment Review Committee. - USA. - P. 42.

6. Guide for the care and use of laboratory animals. LAR Publication, National Academy Press, USA, 1996. P. 22.

7. OECD Principles of Good Laboratory Practice. ENV/MC/CHEM(98)17 // Environment Directorate Organisation for Economic Cooperation and Development, Paris; 1998.

8. Проданчук Г. М. Створення історичного контролю гематологічних показників периферичної крові щурів Wistar Han / Г.М.Проданчук, Т. В. Усенко // Сучасні проблеми токсикології, харчової та хімічної безпеки. - 2015. - № 4 (72). - С. 35-40.

9. USEPA-Pesticides-Fact Sheetfor Epoxiconazole, United States Office of Prevention, Pesticides Environmental Protection and Toxic Substances Agency (7505P), August 2006.

10. Шуляк В. Г. Достижения в области изучения влияния пестицидов на систему кроветворения / В. Г. Шуляк // Современные проблемы токсикологии. 2002. - № 1. - С. 42-53.

11. Новикова И. Клиническая и лабораторная гематология [Электронный ресурс] / И. Новикова. 2017. - Режим доступа: http://www.clinlab.info/ Hemocytology/Reticulocytes-counting-49.

12. Меньшиков В. В. Лабораторные методы исследования в клинике / В. В. Меньшиков. - М. : Медицина, 1987. - С. 106-145.
13. Цитохимия и электронная микроскопия клеток крови и кроветворных органов / [3. А. Бутенко, Д. Ф. Глузман, К. П. Зак и др.]. - К. : Наукова думка, 1974. - С. 28-88.

14. Гаврилов О. К. Депресии кровообразования / О. К. Гаврилов. - М. : Медицина, 1987. - 236 с.

15. Kravtsov V. Nuclear abnormalities of lymphocytes as the simplest markers for bioindication test in case of mass casualty events involving radiation exposure / V. Kravtsov, A. Livanova, Y. Starkova // Emergency Medicine (Los Angel). - 2017. - 7, No. 356.

16. Çayır A. Micronuclei, nucleoplasmic bridges, and nuclear buds induced in human lymphocytes by the fungicide signum and its active ingredients (boscalid and pyraclostrobin) / A. Çayır, C. Munevver, C. Mahmut // Environmental Toxicology. - 2014. - 29, No. 7. - P. 723-732

17. Zeljezic D. Chromosomal aberrations, micronuclei and nuclear buds induced in human lymphocytes by 2 , 4-dichlorophenoxyacetic acid pesticide formulation / D. Zeljezic, V. Garaj-Vrhovac// Toxicology. -2004. -200, Issue 1. - P. 39-47

18. Ефимцева Э. А. Активность эстераз в тканях различных отделов желудочно-кишечного тракта северного оленя / Э. А. Ефимцева, Т. И. Челпанова // Сельскохозяйственная биология. - 2007. - № 6. C. $77-80$.

19. Хундерякова Н. В. Разработка метода определения активности сукцинатдегидрогеназы лимфоцитов как показателя адренергической регуляции в организме : автореф. дисс. на соискание учен. степени канд. биол. наук / Н. В. Хундерякова. - Пущино, 2008. - 121 c

20. Радченко О. М. Клітинний імунітет за умов різних типів адаптаційних реакцій / О. М. Радченко // Медична гідрологія та реабілітація. -2009. - 7, № 3. C. $57-60$.

21. Гнідой І. М. Імунний статус у дітей у разі дії свинцю в низьких дозах / І. М. Гнідой, І. І. Діхтярук // Укр. мед. часоп. - 2002. - № 6 (32), XI-XII. - С. 125127.

22. Приходько О. О. Морфофрункціональні зміни перифреричної крові в умовах дії екзогенних чинників хімічної природи / О. О. Приходько // Вісн. Сум. держ. ун-ту. - 2009. - 1, № 2. - С. 34-42 .

23. Воробель А. В. Основи гематології [Електронний ресурс] / А. В. Воробель. - Режим доступу : http://194.44.152.155/elib/local/349.pdf. 


\section{REFERENCES}

1. Kapliuchenko, A.H. (2016). Praktychne znachennia ta zastosuvannia pokhidnykh 1,2,4-triazolu [Practical value and application of derivatives of 1,2,4-triazole]. Zaporizhzhia: ZDMU [in Ukrainian].

2. (2015). Peer review of the pesticide risk assessment of the active substance epoxiconazole. EFSA Journal, 13 (6), 4123.

3. Chambers, J.E. (2014). Human and ecological risk assessment of a crop protection chemical: a case study with the azole fungicide epoxiconazole. Critical Reviews in Toxicology, 44, 2, 176-210.

4. Schmidt, F. (2016). Effects of combination azole fungicides in male rats in a broad dose range. Toxicology, 355, 54-63

5. EPA MEMORANDUM January 24, 2001 Epoxiconazole - Report of the Cancer Assessment Review Committee, USA, 42.

6 . Guide for the care and use of laboratory animals. LAR Publication, National Academy Press, USA, 1996, 22.

7. (1998) OECD Principles of Good Laboratory Practice. ENV/MC/CHEM(98)17. Environment Directorate Organisation for Economic Cooperation and Development, Paris.

8. Prodanchuk, M.H. (2015). Stvorennia istorychnoho kontroliu hematolohichnykh pokaznykiv peryferychnoi krovi shchhuriv Wistar Han [Create a historical monitoring of hematological parameters of peripheral blood of Wistar rats, Han]. Suchasni problemy toksykolohii, kharchovoi ta khimichnoi bezpeky - Modern Problems of Toxicology, Food and Chemical Safety, 4 (72), 35-40 [in Ukrainian].

9. US EPA - Pesticides - Fact Sheet for Epoxiconazole, United States Office of Prevention, Pesticides Environmental Protection and Toxic Substances Agency (7505P), August 2006.

10. Shulyak, V.G. (2002). Dostizheniya v oblasti izucheniya vliyaniya pestitsidov na sistemu krovetvoreniya [Advances in the study of the impact of pesticides on the hematopoietic system]. Suchasni problemy toksykolohii - Modern Problems of Toxicology, 1, 42 [in Russian]

11. Novikova, S. (2017). Klinicheskaya i laboratornaya gematologiya [Clinical and laboratory paematology]. Retrieved from: http://www.clinlab.info/Hemocytology/ Reticulocytes-counting-49 [in Russian].

12. Menshikov, V.V. (1987). Laboratornye metody issledovaniya $v$ klinike [Laboratory methods in the clinic]. Moscow: Meditsyna [in Russian].

13. Butenko, Z.A. (1974). Tsitokhimiya i elektronnaya mikroskopiya kletok krovi i krovetvornykh organov
[Cytochemistry and electron microscopy of blood cells and blood-forming organs]. Kyiv: Naukova Dumka [in Russian].

14. Havrylov, A.K. (1987). Depresii krovotvorennia [The depression of hematopoiesis]. Moscow: Meditsyna [in Russian].

15. Kravtsov, V. (2017). Nuclear abnormalities of lymphocytes as markers for the simplest bioindication test in case of mass casualty events involving radiation exposure. Emergency Medicine (Los Angel), 7, 356.

16. Çayır, A. (2014). Micronuclei, nucleoplasmic bridges, and nuclear buds induced in human lymphocytes by the fungicide signum and its active ingredients (boscalid and pyraclostrobin). Environmental Toxicology, 29, 7, 723-732

17. Zeljezic, D. (2004). Chromosomal aberrations, micronuclei and nuclear buds induced in human lymphocytes by 2, 4-dichlorophenoxyacetic acid pesticide formulation. Toxicology, 200, 1, 39-47

18. Efimtseva, E.A. (2007). Aktivnost esteraz v tkanyakh razlichnykh otdelov zheludochno-kishechnogo trakta severnogo olenya [The Activity of esterases in different tissues of the gastrointestinal tract of reindeer]. Selskokhozyaystvennaya biologiya-Agricultural Biology, 6, 77-80 [in Russian].

19. Khuneryakova, N.V. (2008). Razrabotka metoda opredeleniya aktivnosti suktsinatdegidrogenazy limfotsitov kak pokazatelya adrenergicheskoy regulyatsii $v$ organizme [Development of a method for determining the activity of succinate dehydrogenase in lymphocytes as an indicator of adrenergic regulation in the body]. Candidate's Extended abstract. Pushchino [in Russian].

20. Radchenko, O.M. (2009). Klitinnyi imunitet za umov riznykh typiv adaptatsiinykh reaktsii [Cellular immunity in conditions of various types of adaptive reactions]. Medychna hidrolohiia ta reabilitatsiia - Medical Hydrology and Rehabilitation, 7, 3, 57-60 [in Ukrainian].

21. Hnidoi, I.M., \& Datarock, I. (2002). Imunnyi status u ditei u razi dii svyntsiu v nyzkykh dozah [Immune status in children with lead exposure in low doses]. Ukrainskyi med. chasopys - Ukrainian Medical Journal, 6 (32), XIXII, 125-127 [in Ukrainian].

22. Prykhodko, E.A. (2009). Morfofunktsionalni zminy peryferychnoi krovi v umovakh dii ekzohennykh chynnykiv khimichnoï pryrody [Morpho-functional changes of the peripheral blood under the action of exogenous chemical factors]. Visnyk Sumskoho derzhanoho un-tu - Bulletin of Sumy State University, 2, 1, 34-42 [in Ukrainian].

23. Vorobel, A.V. Osnovy hematolohii [Fundamentals of hematology]. Retrieved from: http://194.44.152.155/ elib/local/349.pdf [in Ukrainian]. 


\section{ВЛИЯНИЕ ЭПОКСИКОНАЗОЛА НА ГЕМАТОЛОГИЧЕСКИЕ И ЦИТОХИМИЧЕСКИЕ ПОКАЗАТЕЛИ ПЕРИФЕРИЧЕСКОЙ КРОВИ KPЫC WISTAR HANNOVER}

\section{Резюме}

Вступление. Эпоксиконазол - высокоэффрективный фунгицид широкого спектра действия класса триазолов. Он входит в состав многих современных препаратов для борьбы с фритопатогенами. Его широко применяют в сельском хозяйстве мира и Украины в частности. Несмотря на свои гепатотоксичные характеристики, данный фрунгицид нарушает гематологические параметры крови.

Цель исследования - изучить влияние генерического триазольного фунгицида эпоксиконазола $95 \%$ на гематологические и цитохимические показатели перифрерической крови крыс Wistar Hannover в условиях острого эксперимента.

Методы исследования. Исследования проведены на 10 половозрелых крысах-самцах Wistar Han, разделенных на контрольную (О мг/кг) и экспериментальную группы. Животным экспериментальной группы была введена токсическая доза 1580 мг/кг массы тела (1/2 от лд50) однократно внутрижелудочно через зонд. Перифрерическую кровь исследовали на 0 и 1, 3, 7 и 14 сутки после экспозиции. Изучали гематологические показатели: количественное содержание эритроцитов, концентрацию гемоглобина, уровень гематокрита, эритроцитарные индексы (средний объем эритроцита, среднее содержание гемоглобина в одном эритроците, среднюю концентрацию гемоглобина в одном эритроците), количество лейкоцитов и тромбоцитов. Гемограмму с оценкой морфологических изменений клеток крови и процентного соотношения различных видов лейкоцитов исследовали в мазках перифрерической крови. Цитохимический статус лейкоцитов оценивали на основе определения фрерментативной активности нафртол-AS-D-хлорацетатэстеразы в нейтрофилах, сукцинатдегидрогеназы и кислой фросфратазы в лимфоцитах.

Результаты и обсуждение. Эритроцитоз в ответ на интоксикацию пестицидом с уменьшением средней концентрации гемоглобина в одном эритроците, снижение концентрации гемоглобина до конца эксперимента на фроне активной полихромазии свидетельствуют об анемизирующем действии эпоксиконазола. Реактивный нейтрофрилез, стимуляция лимфоцитопоэза и моноцитопоэза, появление в перифрерической крови макрофрагов, увеличение активности нафртол-AS-D-хлорацетатэстеразы, сукцинатдегидрогеназы и кислой фросфатазы расценены как компенсаторные механизмы. Отмечены обратимые количественные изменения в соотношении субпопуляций лимфооцитов по активности кислой фросфратазы.

Вывод. Анализ результатов исследования гематотоксического действия генерического триазольного фрунгицида эпоксиконазола 95 \% в условиях острого эксперимента на крысах-самцах Wistar Hannover показал развитие скрытой анемии, проявившейся в поздние сроки исследования; активизацию моноцитопоэза; увеличение макрофрагов в сосудистом русле; изменения иммунного ответа организма и появление атипичных нормоцитов и лимсоцитов с аномалиями ядер.

КЛЮЧЕВЫЕ СЛОВА: эпоксиконазол; гематотоксичность; анемія; сукцинатдегидрогеназа; кислая фоссратаза; нафттол-AS-D-хлорацетатэстераза; макрофраги; “хвостатые” лимфоциты.

T. V. Usenko, V. G. Shulyak

\section{HEMATOLOGICAL AND CYTOCHEMICAL PARAMETERS OF PERIPHERAL BLOOD OF WISTAR HANNOVER RATS AFTER EXPOSURE TO EPOXICONAZOLE}

\section{Summary}

Introduction. Epoxiconazole is a highly effective triazole fungicide. It is a part of many modern compounds for the control of phytopathogens and widely used in agriculture in all over the world and in Ukraine, in particular. Despite its hepatotoxic characteristics, this fungicide alters the hematological parameters of blood. 
The aim of the study - to investigate the effects of generic triazole fungicide epoxiconazole, $95 \%$ on hematological and cytochemical parameters of peripheral blood of Wistar Hannover rats in acute experiment.

Research Methods. 10 healthy males of Wistar Han rats were equally divided into control (0 mg/kg/bw) and experimental groups. Dose $1580 \mathrm{mg} / \mathrm{kg} / \mathrm{bw}$ of epoxiconazole (1/2 LD50) was administered once orally by gavage to 5 experimental rats. Peripheral blood was studied at 0 and 1, 3, 7, 14 day after exposure (DAE). RBC, HGB, HCT, erytrocyte indices MCV, MCH, MCHC, WBC and PLT were, hemogram and morphological disturbances of cells were studied, percentage ratio of different types of leukocytes was calculated. The cytochemical status of leukocytes was assessed on the basis of determining the enzymatic activity of specific naphthol-AS-D-chloroacetateterase in neutrophils, succinate dehydrogenase and acid phosphatase in lymphocytes.

Results and Discussion. Erythrocytosis in response to pesticide intoxication with a decrease of mean cell hemoglobin concentration in one erythrocyte; the reduction of hemoglobin concentration in the end of experiment against the background of active polychromasia confirmed the anemic effect of epoxiconazole. Reactive neutrophilia, stimulation of lymphocytopoiesis and monocytopoiesis, appearance of macrophages in the peripheral blood, increased activity of naphthol-AS-D-chloroacetateterase, succinate dehydrogenase and acid phosphatase were considered as compensatory mechanisms. Reverse quantitative changes in the ratio of lymphocytes subpopulations based on the activity of acid phosphatase were noted.

Conclusions. Results of the study of generic fungicide epoxiconazole, $95 \%$ hematotoxic activity in the acute experiment on Wistar Hannover male rats showed the development of latent anemia, which was manifested in the late-term study; activation of monocytopoesis; increase of macrophages in the peripheral blood; changes in the immune response of the body and the appearance of atypical normocytes and lymphocytes with nuclear abnormalities.

KEY WORDS: epoxiconazole; hematotoxicity; anemia; succinate dehydrogenase; acid phosphatase; naphthol-AS-D-chloroacetateterase; macrophages; "tailed" lymphocytes.

Отримано 18.01.18

Адреса для листування: Т. В. Усенко, Науковий центр превентивної токсикології, харчової та хімічної безпеки імені академіка л. І. Медведя МОЗ України, вул. Героїв Оборони, 6, Київ, 03127, Україна, e-mail: ksusha528@inbox.ru. 